\title{
Pro Kontra Wacana Pembebasan Narapidana Korupsi di Tengah Pandemi Covid-19
}

\author{
Putri Octavia $^{1}$, Melina Nurul Khofifah ${ }^{2}$ \\ Program Studi Pemikiran Politik Islam IAIN Kudus \\ e-mail: poctta14@gmail.com ${ }^{1}$, melinanurul365@gmail.com²
}

\begin{abstract}
Abstrak
Banyak kebijakan yang telah diterbitkan oleh pemerintah dalam rangka pencegahan penularan Covid-19. Salah satunya adalah keputusan membebaskan narapidana yang digagas oleh Menteri Hukum dan HAM. Menteri Hukum dan HAM juga berencana merevisi Peraturan Pemerintah No. 99 Tahun 2012 tentang Syarat dan Tata Cara Pelaksanaan Hak Warga Binaan Masyarakat. Rencana ini menimbulkan banyak respon dari masyarakat dan lembaga terkait. Artikel ini berusaha mengkaji respon dari masyarakat mengenai rencana pembebasan narapidana korupsi dengan menggunakan teori sistem politik. Penelitian ini merupakan penelitian deskriptif kualitatif dengan menggunakan pendekatan studi kasus. Dari penelitian didapati bahwa alasan rencana pembebasan narapidana korupsi adalah untuk menegakkan Hak Asasi Manusia. Namun, masyarakat memberikan respon penolakan dan tuntutan untuk tidak membebaskan narapidana korupsi karena melanggar HAM masyarakat yang telah dirugikan. Hasil penelitian ini memberikan gambaran jika keputusan berupa output sistem politik akan dipertentangkan bila tidak sesuai kepentingan masyarakat.
\end{abstract}

\section{Kata Kunci:}

Pembebasan, Narapidana, Korupsi, Yasonna Laoly, Covid-19

\section{PENDAHULUAN}

Tulisan ini akan membahas mengenai wacana Menteri Hukum dan Hak Asasi Manusia (Menkumham) Yasonna Laoly untuk merevisi Peraturan Pemerintah (PP) No. 99 Tahun 2012 tentang Syarat dan Tata Cara Pelaksanaan Hak Warga Binaan Masyarakat agar dapat membebaskan narapidana tindak pidana korupsi di tengah pandemi Covid-19. Banyak elemen masyarakat menolak keras rencana dibebaskannya koruptor dengan dalih kemanusian di tengah pandemi Covid-19 ini. Penolakan oleh elemen masyarakat memang didasari rasa kekecewaan warga terhadap narapidana koruptor tersebut, bukan hanya merugikan negara, mereka juga melakukan pelanggaran HAM dengan merampas hak-hak dari warga dan digunakan untuk kepentingan pribadi. Pendapat lainnya mengatakan dengan dibebaskannya para narapidana kasus koruptor sama saja dengan membiarkan 
mereka menginjak-nginjak kembali demokrasi kita. Menggunakan teori sistem politik, tulisan ini ingin menjawab beberapa pertanyaan, yaitu mengapa dilakukan rencana pembebasan narapidana korupsi dengan dalih rasa kemanusiaan di tengah krisis pandemi Covid-19?, dan bagaimana massa merespon wacana revisi PP No. 99/2012 tersebut?.

\section{TINJAUAN PUSTAKA}

Cara kerja sistem politik ini tidak bisa dilepaskan dari David Easton dalam bukunya yang berjudul The Political System (1953). Teori yang dikembangkan oleh Easton ini beranggapan bahwa kehidupan politik adalah kesatuan sistem kegiatan yang berkesinambungan dan saling terkait dalam pembuatan suatu kebijakan otoritatif pemerintahan. ${ }^{1}$

Memahami sistem politik tidak ubahnya memahami cara kerja organ tubuh makhluk hidup. Masing-masing instrumennya mempengaruhi satu sama lain dan bila salah satu tidak berfungsi, maka sistem politik tidak akan bisa berjalan. Energi utama penggerak sistem politik adalah input berupa tuntutan dan dukungan yang berasal dari masyarakat. Nantinya, input akan diolah oleh sistem politik, yaitu proses dan individu yang terlibat dalam pembuatan keputusan di pemerintahan. Hasil dari proses ini adalah output berupa kebijakan untuk dijalankan oleh masyarakat. Output ini akan

\footnotetext{
${ }^{1}$ David Easton, "An Approach to the Analysis of Political Systems", World Politics, Vol. 9, No. 3 (1957), h. 383-400.
}

mendapat respon dari masyarakan hingga kembali menghasilkan tuntutan dan dukungan.

Memaknai istilah sistem politik dapat menggunakan uraian dari Gabriel A. Almond dan G. Bingham Powell. Menurutnya, istilah sistem politik menunjukkan cara baru dalam memandang fenomena politik. Ada beberapa istilah baru untuk hal lama dalam istilah sistem politik, dan istilah baru tersebut merujuk pada aktivitas dan proses yang sebelumnya belum dianggap sebagai bagian dari sistem politik. Almond dan Powell menawarkan analogi layaknya sebuah sirkulasi sistem dalam suatu makhluk hidup. Maknanya dapat dipahami ketika melihatnya sebagai sebuah kesatuan proses tujuan agar organisme dapat berfungsi secara keseluruhan. $^{2}$

Mengacu pada tulisan David Easton, sistem politik memiliki beberapa ciri, yaitu identifikasi, input dan output, pembedaan serta integrasi dalam sistem.

1. Sifat yang diidentifikasi. Yaitu sifat yang membedakan sistem politik dan sistem sosial. Terbagi menjadi dua, yakni unit sistem politik dan batasan. Unit sistem politik adalah elemen yang mendasari terciptanya sistem politik, yaitu tindakan politik. Sedangkan, batasan dalam sistem politik

${ }^{2}$ Gabriel A. Almond, "A Developmental Approach to Political Systems", World Politics, Vol. 17, No. 2 (1965), h. 183-214. 
merupakan tindakan yang berperan dalam pembuatan suatu kebijakan. keharmonisan dalam perumusan suatu kebijakan. ${ }^{3}$
2. Input dan output. Input dalam sistem politik berupa masukan dari masyarakat guna menyuarakan kepentingannya, berupa tuntutan dan dukungan (demands and supports). Secara sederhana, tuntutan adalah kepentingan masyarakat yang belum teralokasikan dengan maksimal oleh otoritas atau pemerintah. Dukungan adalah usaha dari masyarakat untuk melestarikan suatu kebijakan yang diambil oleh sistem politik. Sedangkan output atau keluaran dalam sistem politik merupakan hasil dari tindakan politik para pemagang otoritas. Ini dibagi menjadi dua, yaitu keputusan dan tindakan. Keputusan merupakan kebijakan yang dikeluarkan sebagai respon dari tuntutan dan dukungan. Sedangkan tindakan merupakan implementasi nyata dari keputusan yang diambil.

3. Pembedaan. Yaitu adanya pembagian tugas pada sistem politik di pemerintahan atau otoritas. Pembagian tugas dilakukan agar masing-masing bagian dapat bekerja dengan lain tanpa tumpang tindih dan fokus pada satu bidang.

4. Integrasi. Meskipun terdapat pembedaan dalam sistem politik, kerjasama dan keterpaduan masih menjadi syarat dari berlangsungnya sistem politik. Artinya tetap terjadi

\section{METODE PENELITIAN}

Penelitian ini merupakan penelitian deskriptif kualitatif, yaitu memaparkan hasil penelitian dengan menggunakan kata-kata untuk menjelaskan analisa. Tulisan ini memfokuskan pembahasan pada wacana pembebasan narapidana korupsi yang diutarakan oleh Yasonna Laoly selaku Menkumham. Penulis menggunakan metode observasi dalam menganalisis data berupa informasi tentang wacana tersebut serta respon yang didapat dari massa. Hal tersebut merujuk pada rencana Yasonna Laoly untuk merevisi PP No. 99/2012, serta pendapat berbagai pihak dan masyarakat. Pendekatan yang digunakan merupakan studi kasus berdasarkan pada peristiwa di dalam masyarakat, yang dapat memberikan wawasan serta pengetahuan baru mengenai situasi maupun kondisi tentang suatu kasus. Sumber dari pengumpulan data berasal dari majalah, jurnal, artikel berita, maupun hasil dari pendapat dan saran dari peneliti yang dilakukan secara daring dengan keter-batasan referensi di tengah pandemi.

\section{PEMBAHASAN}

Isu pembebasan para narapidana tindak pidana korupsi di tengah gejolak Covid-19 sempat menjadi perbincangan publik sejak diungkapkan oleh Yasonna Laoly.

${ }^{3}$ David, 1957, h. 383-400. 
Gagasan Menkumham Yasonna Laoly untuk merevisi PP No. 99/2012 dengan dalih pengendalian penyebaran Covid-19 disampaikan dalam rapat bersama Komisi III melalui teleconference pada Rabu 1 April 2020. Dikatakan ada sekitar 35.000 narapidana yang akan dibebaskan merupakan narapidana umum dan anak berdasarkan Peraturan Menteri Hukum dan HAM Nomor 10 Tahun 2020 dan Keputusan Menteri Hukum dan HAM Nomor 19.PK.01.04 tahun 2020.

Yasonna Laoly mengatakan pembebasan tersebut akan melalui seleksi yang kuat. Pertama, yaitu narapidana tindak pidana narkotika dengan masa pidana 5-10 tahun dan telah menjalani $2 / 3$ masa pidananya akan diberi-kan asimilasi di rumah, dari datanya diperkirakan ada 15.442 per hari dan akan terus bertambah. Narapidana tindak pidana korupsi di atas usia 60 tahun yang telah menjalani $2 / 3$ masa pidana ada sekitar 300 orang. Narapidana yang memiliki penyakit kronis dan dinyatakan langsung oleh rumah sakit pemerintah dan telah menjalani $2 / 3$ masa pidana ada sebanyak 1.457 orang. Dan narapidana asing ada sekitar 53 orang.

Menurut Pasal 34 PP No. 99/2012 sebagai berikut:

1. Setiap narapidana dan anak pidana berhak mendapatkan remisi.

2. Remisi sebagaimana dimaksud pada ayat (1) dapat diberikan kepada Narapidana dan Anak Pidana yang telah memenuhi syarat: a. berkelakuan baik; dan

b. telah menjalani masa pidana lebih dari 6 (enam) bulan.

3. Persyaratan berkelakuan baik sebagaimana dimaksud pada ayat (2) huruf a dibuktikan dengan:

a. tidak sedang menjalani hukuman disiplin dalam kurun waktu 6 (enam) bulan terakhir, terhitung sebelum tanggal pemberian Remisi;dan

b. telah mengikuti program pembinaan yang diselenggarakan oleh LAPAS dengan predikat baik. (PP No.99/2012: $3-4)^{4}{ }^{4}$

Hal tersebut langsung mendapat penolakan keras dari berbagai kalangan, mulai dari masyarakat, Komisi Pemberantasan Korupsi (KPK), Indonesian Corruption Watch (ICW), dan lain-lain. ICW menuding Yasonna Laoly menggunakan pencegahan Covid-19 sebagai dalih untuk membebaskan para koruptor dan mengatakan ini hanyalah permainan para elit politik saja. ICW menegaskan bahwa kejahatan kasus korupsi tidak bisa disamakan dengan kasus lainnya, karena bukan hanya merugikan negara dengan menggunakan uang negara untuk kepentingan pribadi tetapi para koruptor

${ }^{4}$ Republik Indonesia, "Peraturan Pemerintah (PP) Republik Indonesia Nomor 99 Tahun 2012, Perubahan Kedua Atas Peraturan Pemerintah (PP) Nomor 32 Tahun 1999 Tentang Syarat Dan Tata Cara Pelaksanaan Hak Warga Negara Binaan Pemasyarakatan" dalam https://peraturan. bpk.go.id/Home/Details/5314/pp-no-99-tahun-2012 diakses 1 Mei 2020. 
juga sudah merusak sistem demokrasi, bahkan dikatakan sebagai pelanggaran HAM.

Presiden Republik Indonesia Joko Widodo juga ikut angkat bicara perihal masalah pembebasan narapidana koruptor melalui revisi PP No. 99/2012. Jokowi mengatakan jika pihak dari pemerintah hanya akan membebaskan narapidana umum saja dengan syarat dan ketentuan yang berlaku dan tidak akan membebaskan narapidana korupsi. Dari pihak Jokowi akan memastikan jika tidak akan membebaskan narapidana tindak kasus korupsi. Dikatakan juga jika perihal pembebasan narapidana koruptor tidak pernah ada pembicaraan dan dibahas dalam rapat, jadi itu hanya rencana dari Yasonna Laoly selaku Menkumham.

Ada pendapat yang mengatakan jika Yasonna Laoly memang sangat ingin memberikan keringanan mengingat sebagai pencegahan terhadap kasus Covid19 mengapa tidak fokus terhadap narapidana kasus umum saja yang sudah pasti narapidananya lebih banyak dari pada narapidana kasus korupsi. Dari jumlah narapidana di Indonesia ada sekitar 200.000-an orang dan 4000 lebihnya merupakan narapidana koruptor. Membebaskan narapidana koruptor dengan alasan pencegahan penularan Covid-19 bukanlah keputusan yang tepat. Karena dari yang kita tahu sendiri bahwa ruang tahanan para koruptor itu terkesan mewah dan lebih baik dari para narapidana kasus umum. Dari isu tentang Lembaga Pemasyarakatan Sukamiskin yang dikata- kan memberikan keistimewah-an satu ruang tahanan untuk satu nara-pidana koruptor dengan hal ini secara tidak langsung para narapidana korupsi sudah melakukan social distancing dan memutus rantai penularan Covid-19. Bahkan Najwa Shihab, seorang presenter ikut berkomentar bahwa pembebasan narapidana koruptor dengan alasan Lembaga Pemasyarakatan over dan tidak baik bila digunakan sebagai tempat pencegahan Covid-19 hanya akal-akalan para elit saja. ${ }^{5}$ Para narapidana korupsi di Lembaga Pemasyarakatan Sukamiskin bahkan tergolong hidup mewah.

Yasonna Laoly membantah jika ia melakukan hal ini dengan maksud khusus dan semua murni untuk kebaikan bersama. Yasonna Laoly mengatakan orang yang tidak punya rasa kemanusiaan saja yang tidak setuju dengan pembebasan narapidana dari Lembaga Pemasyarakatan dengan kondisi over kapasistas yang dialami Lembaga Pemasyarakatan di tengah pandemi Covid-19. Pernyataan tersebut untuk merespon sejumlah pihak yang tidak memperikan persetujuannya dengan rencana dari pemerintah untuk membebaskan para narapidana. ${ }^{6}$

${ }^{5}$ Arifina Cahyati Firdausi, "Najwa Shihab Kritik Menteri Yasona Soal Wacana Pembebasan Napi Koruptor, "Mba Nana" Ramai di Twitter", dalam https://jatimtimes.com/baca/212195/2020 0405/173400/najwa-shihab-kritik-menteri-yasonasoal-wacana-pembebasan-napi-koruptor-mba-nanaramai-di-twitter diakses 1 Mei 2020.

${ }^{6}$ CNNIndonesia.com,"Yasonna: Hanya Orang Tumpul Kemanusiaan Tak Terima Napi Bebas" dalam https://www.cnnindonesia.com /nasional /20200405120144-12-490439/yasonna-hanya- 
Yasonna Laoly sudah menandatangani Keputusan Menteri (Kepmen) Nomor M.HH-19.PK.01.04.04 Tahun 2020 tentang Pengeluaran dan Pembebasan Narapidana dan Anak melalui asimilasi dan integrasi dalam rangka pencegahan dan penanggulangan penyebaran Covid-19 pada 30 Maret 2020. Dengan adanya pembebasan tersebut akan menghemat anggaran negara tentang uang pembinaan warga binaan hingga Rp. 260 Miliar. ${ }^{7}$

Masyarakat banyak yang mengkritik kebijakan yang dibuat Yasonna Laoly terhadap pembebasan sejumlah narapidana yang termasuk pembebasan narapidana korupsi melalui revisi PP No. 99/2012. Hal tersebut langsung dibantah oleh Yasonna Laoly, ia mengatakan narapidana yang dipertimbangkan bukan hanya narapidana korupsi tetapi narapidana khusus juga dipertimbangkan untuk dibebaskan dari Lembaga Pemasyarakatan dengan Permenkumham 10/2020 dan Kepmenkumham Nomor M.HH-19.PK.01.04.04 Tahun 2020 tidak boleh menabrak peraturan PP 99/2012. ${ }^{8}$

\section{Komisi Pemberantasan Korupsi (KPK)} ikut menolak keras pembebasan para koruptor. KPK sudah cukup kecewa terhadap Menteri Hukum dan HAM yang mempermudah para koruptor untuk

orang-tumpul-kemanusiaan-tak-terima-napi-bebas diakses 1 Mei 2020

${ }^{7}$ CNNIndonesia.com, 1 Mei 2020.

${ }^{8}$ Patricia Debora Yunita, "Analisis Yuridis Persyaratan Khusus Pembebasan Bersyarat Bagi Narapidana Tindak Pidana Korupsi (Studi Kasus Narapidana Hartati Murdaya)", Jurnal Hukum Universitas Brawijaya (2015), h. 1-21. mendapatkan remisi dan pembebasan bersyarat, hal ini bisa menjadi salah persepsi yang membuat para koruptor menganggap remeh sanksi yang diberikan meskipun para koruptor mendapatkan hukuman berat. Sekarang ditambah lagi dengan pembebasan para koruptor, hukuman mereka sebenarnya sudah mendapatkan banyak ruang kosong tetapi sekarang masih siberi kelonggaran lagi. Wakil Ketua KPK Nurul Ghufron mengatakan jika pembebasan narapidana di tengah gejolak Covid-19 ini harus mengedepankan rasa keadilan. ${ }^{9}$

Memang dapat dilihat hubungan antara pemerintah (elit) dan masyarakat (massa) tidak pernah baik, selalu ada kesenjangan. Pembebasan narapidana ini juga dapat kita lihat sebagai permasalahan yang ada pada hubungan elit dan massa, hal ini terjadi akibat perbedaan posisi yang dimiliki oleh pemerintah dan masyarakat. Terjadi pertentangan dan konflik antara elit yang berposisi sebagai kelompok dominan yang dapat melakukan dominasi terhadap massa yang berposisi sebagai kelompok subordinasi. Posisi yang berbeda menghasilkan kepentingan yang berbeda pula hal ini menjadi potensi dari konflik yang melekat pada elit dan massa. Kesimpulannya konflik di antara elit dan massa terbentuk karena tidak tercapainya titik

${ }^{9}$ Dhika Kusuma Winata, "Wakil Ketua KPK Tolak Rencana Pembebasan Napi Koruptor" dalam https://mediaindonesia.com/read/detail/301235wakil-ketua-kpk-tolak-rencana-pembebasan-napikoruptor diakses 1 Mei 2020. 
temu perbedaan kepentingan di antara mereka. ${ }^{10}$

Masyarakat yang sepenuhnya menerapkan nilai-nilai demokrasi akan menyelesaikan masalah yang muncul dari pertentangan kepentingan antara elit dan massa dengan jalan yang cenderung mekanis. Penyelesaian masalah yang bisa menghadirkan pertentangan di antara keduanya didasarkan pada tata cara yang telah disepakati bersama di antara anggota masyarakat. Tata cara yang disepakati tersebut diberlakukan menjadi suatu norma yang harus ditaati oleh seluruh anggota masyarakat yang bersangkutan. ${ }^{11}$

Berdasarkan hal tersebut Presiden Indonesia Joko Widodo angkat suara, dia menegaskaan jika masalah pembebasan narapidana hanya berlaku bagi narapidana tindak pidana umum, sementara narapidana koruptor, narkoba dan teroris tidak akan dibebaskan dalam kebijakan tersebut. Dengan ini pemerintah tidak akan pernah merevisi PP No. 99/2012 yang berisi perihal regulasi pengetatan hukuman bagi narapidana khusus termasuk koruptor yang disampai-kan dalam rapat secara virtual di Istana Bogor pada Senin, tertanggal 06 April 2020. ${ }^{12}$

${ }^{10}$ Haryanto, Elit, Massa dan Kekuasaan: Suatu Bahasan Pengantar (Yogyakarta:PolGov, 2017).

${ }^{11}$ Edie Toet Hendratno, "Kebijakan Pemberian Remisi Bagi Koruptor, Suatu Telaah Kritis Dari Perspektif Sosiologi Hukum", Jurnal Hukum dan Pembangunan, Vol. 44, No.4 (2013), h. 518-542.

${ }^{12}$ Andhika Prasetia, "Jokowi: Hanya Napi Pidana Umum yang Dibebaskan terkait Corona, Bukan Koruptor" dalam https://news.detik.com
Pemerintah juga tidak membebaskan narapidananya dengan asal saja, tetapi harus dengan ketentuan syarat, kriteria dan pengawasan tertentu. Seperti di beberapa negara yang juga melakukan pembebasan terhadap narapidana mereka dalam pencegahan penyebaran Covid-19 seperti di Iran yang membebaskan 95.000 narapidana dan Brasil yang membebaskan 34.000 narapidana.

Mahfud MD selaku Menko Polhukam juga mengatakan melalui keterangan resminya pada tanggal 04 April 2020, jika pemerintah sama sekali tidak akan mengubah atau merevisi PP No. 99/2012 tersebut. Pihak pemerintah sendiri akan tetap pada sikap awal mereka dengan tidak menganggu hingga merevisi aturan tersebut. Mahfud MD menjelaskan jika di dalam PP No. 99/2012 sudah tertera dengan jelas jika narapidana tindak pidana korupsi, narkoba, dan teroris itu berbeda dengan narapidana tindak pidana umum. ${ }^{13}$ Dan dari Lembaga Pemasyarakatan yang ditempati oleh narapidana koruptor pun tidak terlalu padat sehingga tidak memiliki potensi untuk penyebaran Covid-19. Dengan begini tuntutan masyarakat diterima pemerintah dan pembebasan narapidana korupsi, narkoba serta teroris tidak akan dibebaskan.

\footnotetext{
/berita/d-4966490/jokowi-hanya-napi-pidanaumum-yang-dibebaskan-terkait-corona-bukankoruptor diakses 1 Mei 2020.

${ }^{13}$ Feriawan Hidayat, "Mahfud MD: Tidak Ada Pembebasan Bersyarat Napi Koruptor" dalam https://www.beritasatu.com/nasional/616839mahfud-md-tidak-ada-pembebasan-bersyarat-napikoruptor diakses 1 Mei 2020.
} 


\section{KESIMPULAN}

Rencana Yasonna Laoly untuk merevisi PP No. 99/2012 mendapat penolakan dari berbagai pihak, sebab Menteri Hukum dan HAM tersebut berencana untuk membebaskan narapidana koruptor dengan alasan darurat Covid-19. Yasonna Laoly membantah jika ia melakukan hal ini dengan maksud khusus dan semua murni untuk kebaikan bersama. Selain itu, Yasonna Laoly berdalih pihak yang menolak keputusannya tidak memiliki rasa kemanusiaan karena membiarkan narapidana dalam Lembaga Pemasyarakatan yang over kapasitas. Pernyataan tersebut mendapat respon penolakan dari berbagai pihak sebab berpeluang mencederai Hak Asasi Manusia masyarakat luas yang haknya dirampas oleh koruptor. Beberapa pihak pun membantah jika Lembaga Pemasyarakatan narapidana korupsi over kapasitas karena fasilitasnya yang lengkap. Dengan tekanan dari banyak elemen masyarakat, rencana pembebasan narapidana korupsi tersebut akhirnya batal dilaksanakan.

$$
* * *
$$

\section{DAFTAR PUSTAKA}

David Easton, "An Approach to the Analysis of Political Systems", World Politics, Vol. 9, No. 3 (1957), h. 383400.

Edie Toet Hendratno, "Kebijakan Pemberian Remisi Bagi Koruptor, Suatu Telaah Kritis Dari Perspektif Sosiologi Hukum", Jurnal Hukum dan
Pembangunan, Vol. 44, No.4 (2013), h. 518-542.

Gabriel A. Almond, "A Developmental Approach to Political Systems", World Politics, Vol. 17, No. 2 (1965), h. 183-214.

Haryanto, Elit, Massa dan Kekuasaan: Suatu Bahasan Pengantar (Yogyakarta: PolGov, 2017).

Patricia Debora Yunita, "Analisis Yuridis Persyaratan Khusus Pembebasan Bersyarat Bagi Narapidana Tindak Pidana Korupsi (Studi Kasus Narapidana Hartati Murdaya)", Jurnal Hukum Universitas Brawijaya (2015), h. 1-21.

Republik Indonesia, "Peraturan Pemerintah (PP) Republik Indonesia Nomor 99 Tahun 2012, Perubahan Kedua Atas Peraturan Pemerintah (PP) Nomor 32 Tahun 1999 Tentang Syarat Dan Tata Cara Pelaksanaan Hak Warga Negara Binaan Pemasyarakatan" dalam https://peratu ran. bpk.go.id/Home/Details/5314/ppno-99-tahun-2012 diakses 1 Mei 2020.

\section{Website}

Andhika Prasetia, "Jokowi: Hanya Napi Pidana Umum yang Dibebaskan terkait Corona, Bukan Koruptor" dalam https://news.detik.com /berita/ d-4966490/jokowi-hanya-napi-pidana -umum-yang-dibebaskan-terkait-coro na-bukan-koruptor diakses 1 Mei 2020.

Arifina Cahyati Firdausi, "Najwa Shihab Kritik Menteri Yasona Soal Wacana 
Pembebasan Napi Koruptor, "Mba Nana" Ramai di Twitter", dalam https://jatimtimes.com/baca/212195/2 020 0405/173400/najwa-shihab-kritikmenteri-yasona-soal-wacana-pembeba san-napi-koruptor-mba-nana-ramaidi-twitter diakses 1 Mei 2020.

CNNIndonesia.com,"Yasonna: Hanya Orang Tumpul Kemanusiaan Tak Terima Napi Bebas" dalam https://www.cnnindonesia.com/nasion al/20200405120144-12-490439/yason na-hanya-orang-tumpul-kemanusiaantak-terima-napi-bebas diakses $1 \mathrm{Mei}$ 2020.

Dhika Kusuma Winata, "Wakil Ketua KPK Tolak Rencana Pembebasan Napi Koruptor" dalam https://media indonesia.com/read/detail/301235-

wakil-ketua-kpk-tolak-rencana-pembe basan-napi-koruptor diakses $1 \mathrm{Mei}$ 2020.

Feriawan Hidayat, "Mahfud MD: Tidak Ada Pembebasan Bersyarat Napi Koruptor" dalam https://www.berita satu.com/nasional/616839-mahfudmd-tidak-ada-pembebasan-bersyaratnapi-koruptor diakses 1 Mei 2020. 